Case Report

\title{
Pure leydig cell tumour - a rare virilizing tumour in a young female
}

\author{
Patwardhan P.P. ${ }^{1}$, Kolhe A. ${ }^{2}$, Chaturvedi R. ${ }^{3}$, Joshi A.S. ${ }^{4}$ \\ ${ }^{1}$ Dr.Pranav Pramod Patwardhan, Resident, Pathologist, ${ }^{2}$ Dr. Ashvini Kolhe, Assistant Professor, ${ }^{3}$ Dr.Rachana Chaturvedi, \\ Associate Professor, ${ }^{4}$ Dr. Amita S. Joshi, Professor and Head of Department, all authors are affiliated with Department of \\ Pathology, Seth G S Medical College.
}

Corresponding Author: Dr. Ashvini Kolhe, Assistant Professor, Department of Pathology, Seth G.S. Medical College, Mumbai. Email id: drashvinikolhe@gmail.com

\begin{abstract}
Sex cord stromal cell tumours constitute $5-8 \%$ of all ovarian neoplasms of which pure leydig cell tumours constitute $0.1 \%$. These tumours are most commonly found in the post-menopausal age group and patients present with a rapid onset of symptoms of androgen excess like hoarseness of voice, clitoromegaly and hirsutism. We present a case of 39 year old female, who presented with virilising symptoms since 2 years. Serum Testosterone levels were raised and CT revealed homogeneously enhancing mass of $2.8 \mathrm{~cm}$ in size in the right ovary. An unilateral oophorectomy was done and sent for histopathological examination. On Gross examination, the ovary revealed the presence of a well circumscribed greyish white tumour with multiple yellowish areas. Microscopy revealed features suggestive of pure leydig cell tumour with reinke crystals. Post operatively, the patient improved symptomatically. The unusual features seen in this case were younger age at presentation and insidious onset of symptoms. The presentation of pure leydig cell tumour- hilar type at such a young age is extremely uncommon.
\end{abstract}

Key words: Leydig cell tumours, Virilizing ovarian tumours

\section{Introduction}

Sex cord stromal cell tumours constitute $5-8 \%$ of all ovarian neoplasms of which pure leydig cell tumours constitute $0.1 \%$ [1]. These tumours are most commonly found in the post-menopausal age group and patients present with a rapid onset of symptoms of androgen excess like hoarseness of voice, clitoromegaly and hirsutism. We present a case of pure Leydig cell tumour of the ovary which presented at a younger age group and with an insidious onset of symptoms. The tumour also had an unusual appearance on gross examination though it showed the classical histomorphological features. This case highlights the possibility of the occurrence of this tumour at a younger age and also the unusual features on gross examination which may be seen in such cases.

Awareness of such unusual features would help in early suspicion and diagnosis of such tumours in the future.

\section{Case Report}

39 year old female, presented with complaints of amenorrhea, weight gain and increase in the hair growth over the body since 4 years. There was no other major surgical/ medical past history. On general examination, the patient had darkening of the face with hirsutism over the face, limbs, chest and the abdomen. On genital examination, Clitoromegaly was present and the vagina was moist and estrogenised. On laboratory investigations, SGOT was 28 U/L; SGPT 22 U/L; Serum Testosterone $4.91 \mathrm{ng} / \mathrm{ml}$ (Raised); Serum FSH $5.58 \mathrm{mIU} / \mathrm{ml}$; Serum LH $9.3 \mathrm{mIU} / \mathrm{ml}$ and Serum ACTH 19.3 $\mathrm{pg} / \mathrm{ml}$. USG revealed a hypo-isoechoic lesion of size $2.1 \times 2.5 \mathrm{~cm}$ in the right adnexa with both internal and peripheral high vascularity and separate right ovary with multiple small follicles. CT abdomen also revealed a homogeneously enhancing mass of $2.8 \mathrm{~cm}$ in size in the ovary suggestive of a right sided ovarian neoplasm. (fig 1) PET scan showed a hypermetabolic focus in the right ovary. There was no evidence of metabolically active focus anywhere else in the body. An unilateral oophorectomy was done and sent for histopathological examination.

Manuscript received: $6^{\text {th }}$ January 2018

Reviewed: $15^{\text {th }}$ January 2018

Author Corrected: $23^{\text {rd }}$ January 2018

Accepted for Publication $27^{\text {th }}$ January 2018 
Case Report

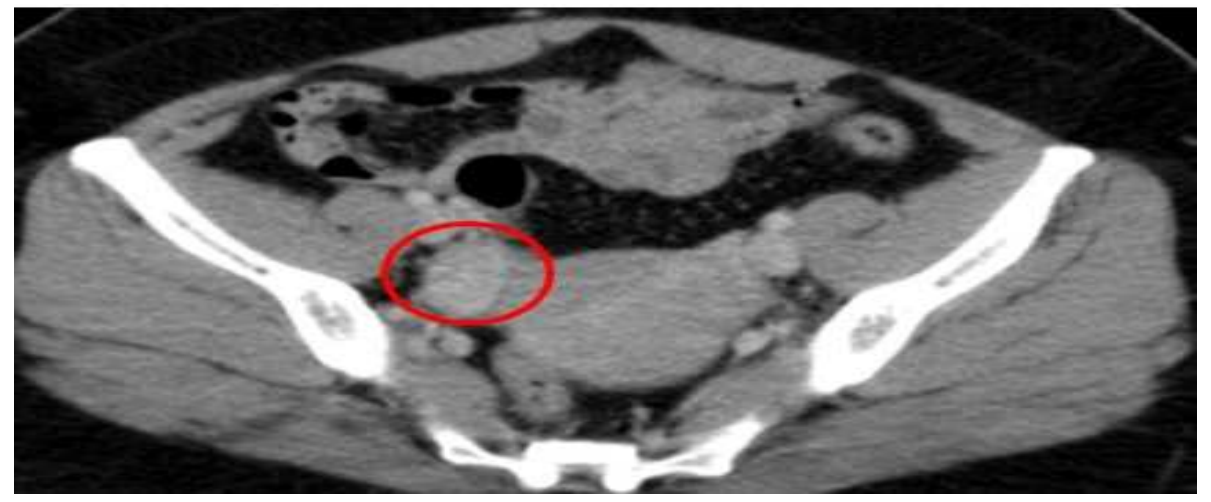

Figure-1: CT scan: Homogeneously enhancing mass of $2.8 \mathrm{~cm}$ in size in the right ovary

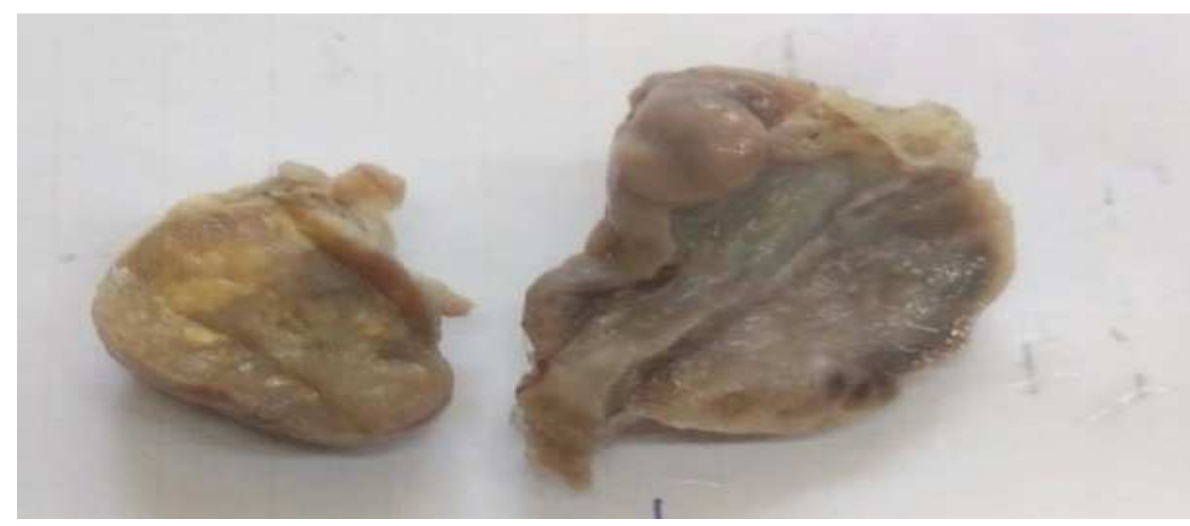

Figure-2: Ovary received in the form of two nodular bits. Cut surface of the smaller bit showed a $2 \mathrm{~cm}$ homogeneous yellowish area.

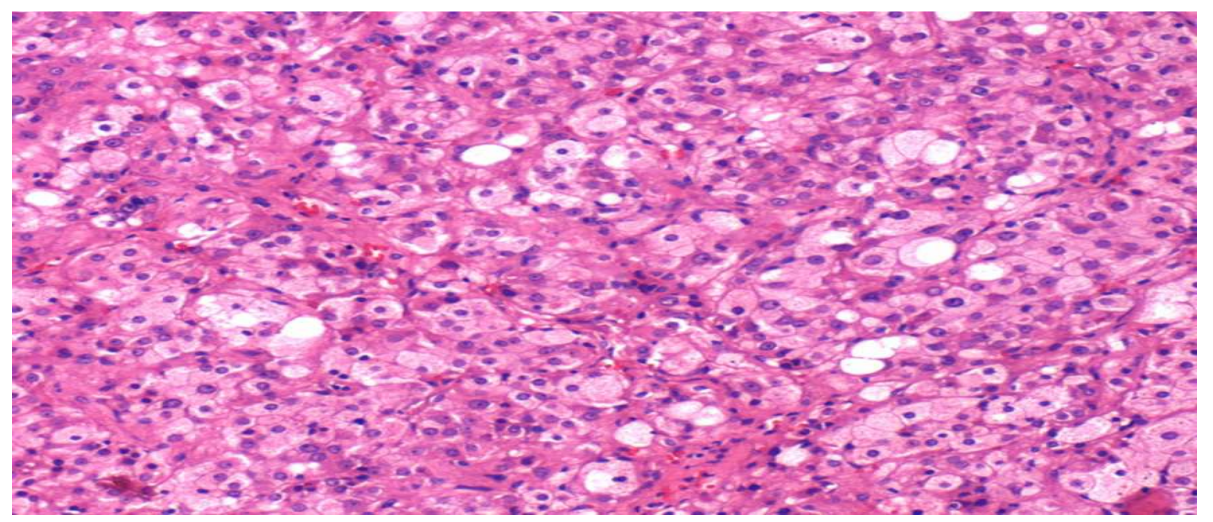

Figure-3: Tumour cells arranged in sheets and trabeculae and having vacuolated cytoplasm (HE X 40).

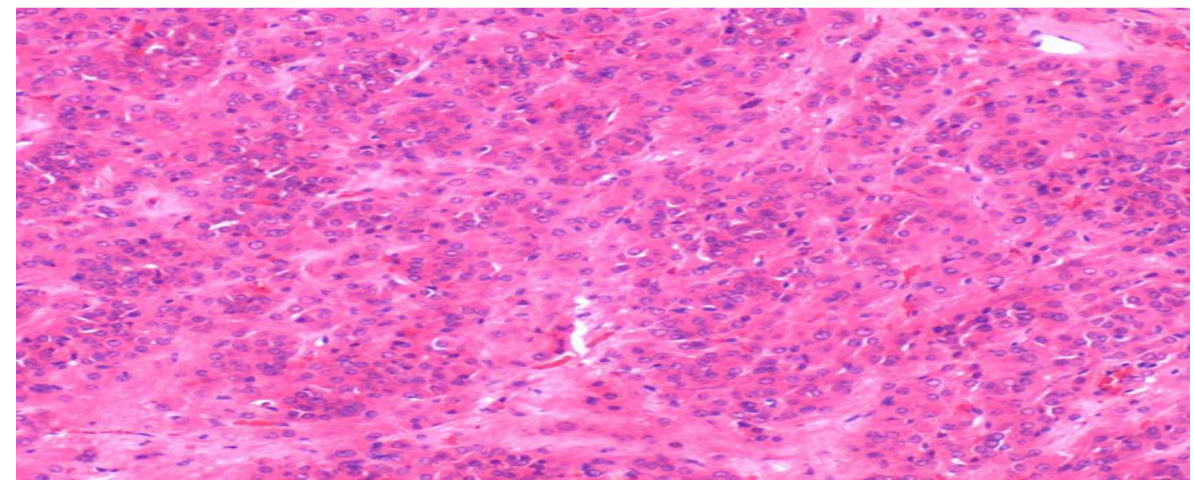

Figure-4: Tumour cells showing dense eosinophilic cytoplasm (HE X 100) 


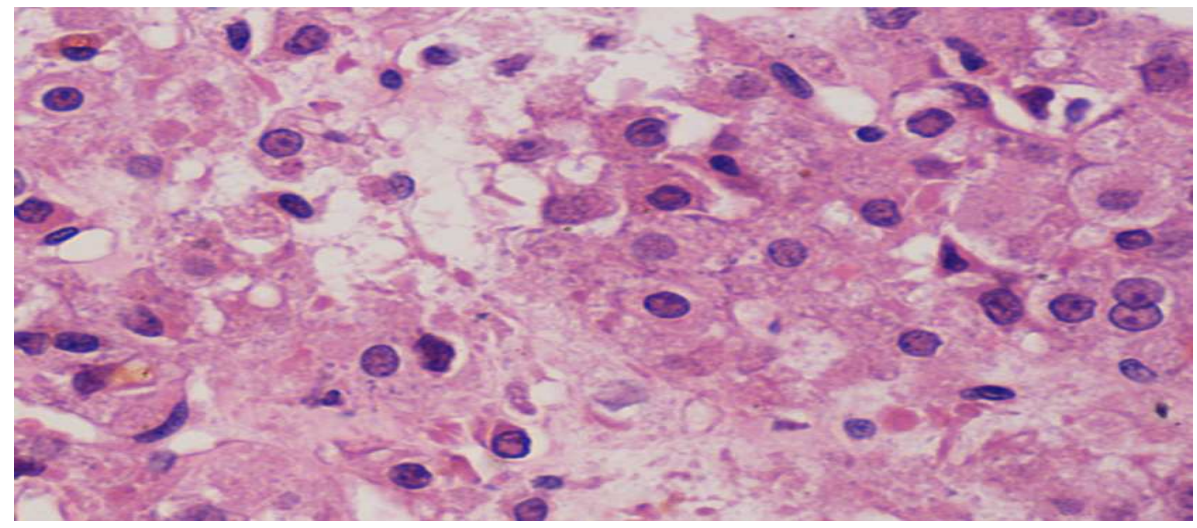

Figure-5: Intracellular hexagonal Reinke crystals seen (HE X 400)

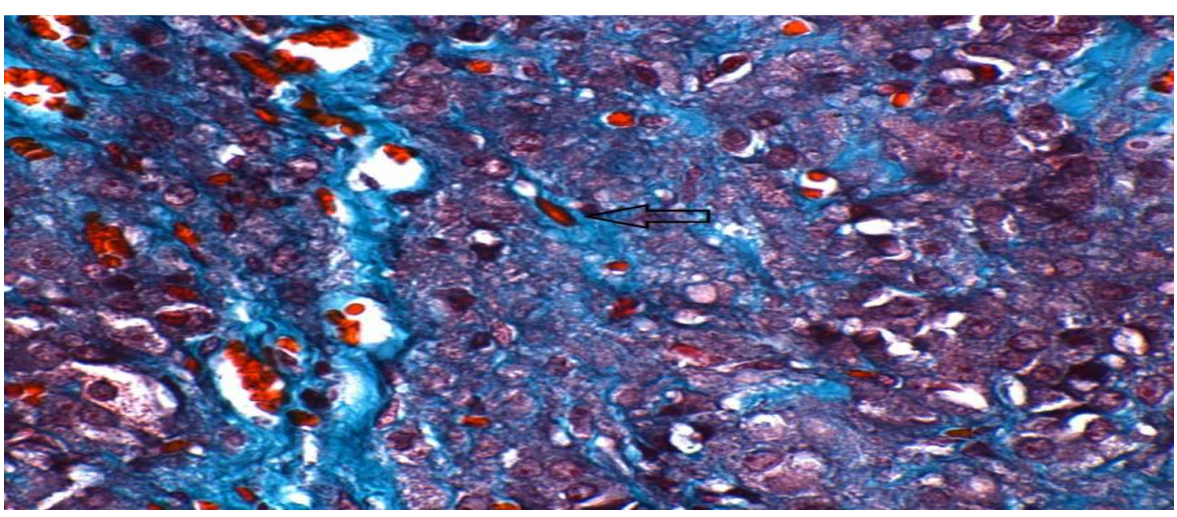

Figure-6: Reinke crystals highlighted by Masson Stain

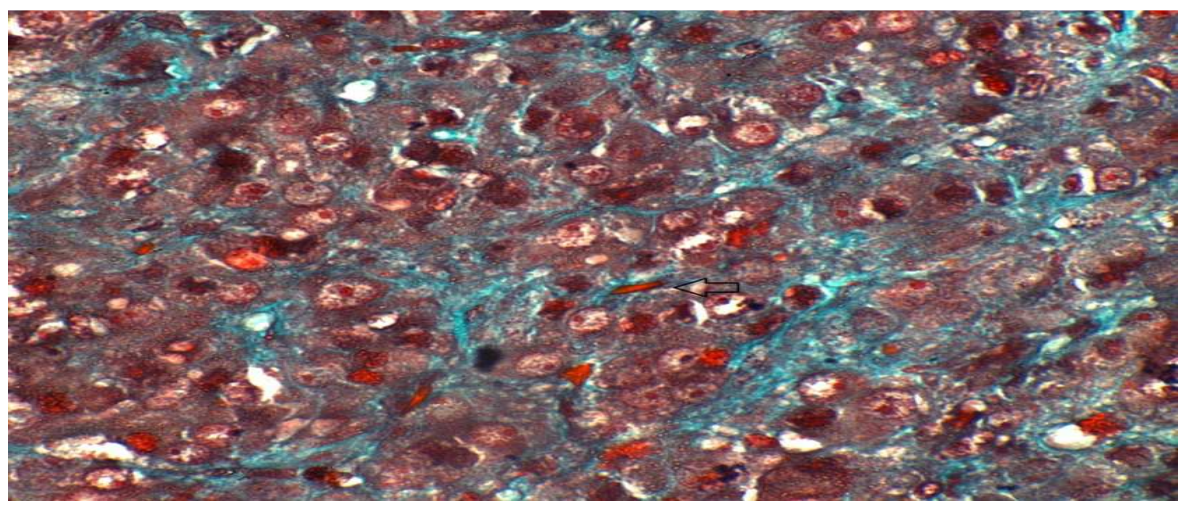

Figure-7: Reinke crystals highlighted by Masson Stain

Gross and Microscopic examination: Right oophorectomy specimen was received in the form of 2 nodular bits. The larger bit measuring $3.5 \times 2 \times 1.5 \mathrm{~cm}$ showed normal ovarian parenchyma on cut section. (fig 2) The smaller bit measured 2 X 2 X $1.5 \mathrm{~cm}$ with cut section showing a well circumscribed, greyish white area with few yellow spots (fig 2). Microscopy showed the tumour to be partly encapsulated and was composed of cells arranged in sheets, nodules, solid pattern as well as in trabeculae. Some of the cells showed vacuolated cytoplasm (fig 3) while others showed dense eosinophilic cytoplasm (fig 4) containing hexagonal eosinophilic "Reinke crystals" (fig 5) which were highlighted by Masson Trichrome stain (fig 6 \& 7). These crystals clinched the diagnosis of Leydig cell tumour.

\section{Discussion}

Sex cord stromal tumors account for $5-8 \%$ of all ovarian tumours [1]. These tumours are classified into granulosa stromal cell tumours, sertoli stromal cell tumours, sex cord stromal tumours with annular tubules, gyandroblastoma and steroid cell tumours according to the WHO classification [2]. 


\section{Case Report}

The term 'Steroid cell tumour' reflects the morphology and the functionality of the tumour. Leydig cell tumours are rare type of steroid cell tumours which constitute $0.1 \%$ of all ovarian neoplasms [3-4]. They commonly present in the post-menopausal group. Occasional case reports of leydig cell tumour in the ovary have been described at a younger age group [5-7]. Most of these cases described belong to the leydig cell tumourstromal type and very few cases of pure leydig cell tumour ovary - hilar type presenting at a younger age have been described in the literature.

Patients usually present with a rapid onset of virilizing symptoms like amenorrhea, hirsutism and clitoromegaly. The presentation of these symptoms in cases of leydig cell tumour is much faster than that due to other causes of hyperandrogenism [8]. However, our case has a relatively insidious progression of symptoms. Radiologically, these tumours are most often confined to the ovary and are solid homogeneous masses as described in our case.

These tumours are classified into hilar cell tumours and stromal cell tumours. Hilar cell tumours arise from the hilar leydig cells, which are found in $80-85 \%$ of postpubertal ovaries, in association with non-myelinated nerve fibres. These tumours are generally unilateral and benign. They range in size from $1-15 \mathrm{~cm}$ but majority of the tumours are less than $5 \mathrm{~cm}$ in size. Macroscopically, these tumours are solid, fleshy and well circumscribed and appear yellow, orange or brown in colour [9]. Hilar Leydig cell tumours present with milder androgenic manifestations than sertoli leydig cell tumours. They are also relatively smaller on radiology compared to sertoli leydig cell tumours[5].

Stromal leydig cell tumours are rarer, arising from the ovarian stromal cells which differentiate into leydig cells. They are usually multi nodular and lobulated on gross appearance. In our case, the tumour was composed of greyish white areas with multiple small yellowish foci. The appearance was slightly variegated as compared to the classical homogeneous yellowish appearance.

Microscopically, these tumours are composed entirely or predominantly of leydig cells arranged diffusely and in nests. The cells have abundant eosinophilic cytoplasm and round, hyperchromatic nuclei. Presence of reinke crystals is diagnostic of leydig cell tumours. Reinke crystals are elongated hexagonal, intra-cytoplasmic eosinophilic crystals. In the absence of reinke crystals, these tumours are classified as steroid cell tumours.
Hilar leydig cell tumours may show perivascular clustering and fibrinoid necrosis while stromal cell tumours show nests of leydig cells admixed with spindle and ovoid stromal cells simulating the appearance of stromal hyperthecosis or thecoma.

Microscopy in our case showed the tumour to be composed of foci of leydig cell clusters and few clusters consisting of cells with vacuolated cytoplasm resembling steroid cells. Diagnostic reinke crystals were highlighted in the tumour cells. The background showed many hilar blood vessels and nerve fibres suggestive of the hilar location of the tumour. Lipofuscin pigment was also identified in few of the tumour cells, which is a rare feature of this tumour on microscopy.

The spread to the extraovarian structures determines the type of surgery rather than the clinical and radiological features. A conservative oophorectomy is performed if the tumour is confined to the ovary as was done in our case. A total abdominal hysterectomy with bilateral salpingoophorectomy is done in case of extraovarian spread of the disease. The tumour is generally benign in behaviour.

This case highlights the unusual presentation of this rare ovarian tumour at a younger age, the unusual gross appearance of the tumour and the classical histomorphology of such tumours. Presentation of pure leydig cell tumour of the ovary- hilar type at a younger age is extremely rare.

\section{Conclusion}

Pure leydig cell tumour is an uncommon ovarian tumour presenting in the postmenopausal age group with rapidly developing androgenic manifestations. However, it may also present at an earlier age and with a relatively insidious onset and ususual gross appearance. Awareness of such an occurrence would help in early diagnosis and treatment in the future.

This case report creates awareness about the occurrence of these rare tumours in an unexpected age group and also the unusual gross features of the tumour.

\section{Funding: Nil, Conflict of interest: None. Permission of IRB: Yes}

\section{References}

1. Cronje H S, Niemond I, Barn R H, Woodruff JD. Review of the granulose- The carcinoma cell tumors from the Emil Novak Ovarian tumor registry. Am J Obstet Gynecol 1999;180:325-7. 


\section{Case Report}

2. World Health Organization Classification of tumors. pathology and genetics of tumors of the breast and femal genital organs. Lyon: IARC Press; 2014.

3. Nardo LG, Ray DW, Laing I, Williams C, Mc Vey RJ, Seif MW. Ovarian Leydig cell tumor in a perimenopausal woman with severe hyperandrogenism and virilization. Gynecol Endocrinol. 2005 Oct; 21 (4): 238-41.

4. Haji AG, Sharma S, Babu M, Vijaykumar D, Chitrathara K. Androgen secreting steroid cell tumor of the ovary in a young lactating women with acute onset of severe hyperandrogenism: a case report and review of literature. J Med Case Reports 2007. 18 (1): 182.

5. Murali Mohan KV, Shanti V, Rama Krishna BA, Niroopama P, Anitha M. Virilizing ovarian leydig cell tumour. J Clin Sci Res 2013;2:101-4
6. Takeuchi Satoshi, Ishihara Naonon, Ohbayshi Chiho, Itoh Hiroshi, Maruo Takeshi. Stromal leydig cell tumour of ovary: Case Report and literature review. International Journal of Gynecological Pathology. April 1999

7. Soheila Aminimoghaddam, Atefeh Sadat Ebrahimi, Forough Hashemi. A rare ovarian tumor, leydig stromal cell tumor, presenting with virilization: a case report. Med J Islam Repub Iran. 2012 Nov: 26(4): 185-8

8. Faria AM, Perez RV, Marcondes JA, Freire DS, Blasbalg R, Soares J, et al. A premenopausal woman with virilization secondary to an ovarian Leydig cell tumor. Nat Rev Endocrinol. 2011 Apr; 7(4):240-5.

9. Paraskevas M, Scully RE. Hilus cell tumor of the ovary.A clinicopathological analysis of 12 Reinke crystal-positive and nine crystal-negative cases. Int $\mathbf{J}$ Gynecol Pathol. 1989;8(4):299-310.

\section{How to cite this article?}

Patwardhan P.P, Kolhe A, Chaturvedi R, Joshi A.S. Pure leydig cell tumour - a rare virilizing tumour in a young female. Int J Med Res Rev 2018;6(01):60-64. doi:10.17511/ijmrr. 2018.i01.10. 